\title{
Histone Deacetylase Inhibitors can Repress Proliferation and Induce Apoptosis in Gingiva Progenitor Cells from Idiopathic Gingival Fibromatosis
} Zhi Jia" ${ }^{1 \#}$, Chunyue Feng ${ }^{1,2 \#}$, Yingchenyao Wang ${ }^{1}$, Jingkun $\mathrm{Li}^{1}$, Tingting Zhang ${ }^{3}$, Jian Zhang ${ }^{3}$ and Dayong Liu'*

\author{
${ }^{1}$ Department of Endodontics, Tianjin Medical University School of Stomatology, Tianjin, 300070, PR China \\ ${ }^{2}$ Department of Stomatology, PLA 254 Hospital, Tianjin, 300141, PR China \\ ${ }^{3}$ Department of Oral Maxillofacial Surgery, Tianjin Medical University School of Stomatology, Tianjin, 300070, PR China \\ \#These authors contribute equally to this work
}

\begin{abstract}
Objective: Idiopathic gingival fibromatosis (IGF), which is characterized by diffuse enlargement of the gingiva due to expansion and accumulation of connective tissue, is a relatively rare hereditary condition that has no specific cause. The aim of this study was to investigate whether the anti-tumor drugs trichostatin A (TSA; inhibits histone deacetylase) and panobinostat (LBH589; a non-selective inhibitor of histone deacetylase) inhibit the proliferation of cells derived from gingiva in patients with IGF.
\end{abstract}

Materials and methods: After osteogenic differentiation and adipogenic induction, the differences between normal gingival mesenchymal stem cells ( N-GMSCs) and hyperplastic gingival mesenchymal stem ( H-GMSCs, thel cells from IGF ) were determined in terms of alkaline phosphatase staining and activity, alizarin red staining, calcium-nodule formation and, lipid droplets,. The effects of TSA and LBH589 were investigated via the MTT assay, flow cytometry, and reverse transcription polymerase chain reaction (RT-PCR).

Results: Alkaline phosphatase staining and activity, alizarin red staining, lipid droplets detected the differentiative capacity in normal and IGF cells. These assays indicated that IGF cells possess multipotent differentiation properties similar to those of normal cells. RT-PCR showed that mRNA levels of the gene encoding $\mathrm{p} 21^{\text {WaflCip } 1}$, a cyclin-dependent kinase inhibitor and an essential regulator of growth inhibition, were lower in H-GMSCs than in N-GMSCs. After exposure to 1000 nM TSA or 1000 nM LBH589 for 48 h, p21 Waf/Cip1 mRNA levels increased in H-GMSCs.

Conclusions: TSA and LBH589 can repress the growth and proliferation of hyperplastic IGF cells by regulating p21 ${ }^{\text {Waflip1 }}$ mRNA levels.

Keywords: Histone deacetylase inhibitor; Idiopathic gingival fibromatosis; Cell proliferation; Trichostatin A; LBH589, p21 $1^{\text {Waf/Cip1 }}$

\section{Introduction}

\section{Background}

Idiopathic gingival fibromatosis (IGF) [1-3] is a rare oral disease in infants characterized by slow and progressive enlargement of both the maxillary and mandibular gingiva, with normal color and a firm consistency that is non-hemorrhagic and asymptomatic. Gingival enlargement may affect marginal gingiva, attached gingiva, and interdental papilla. IGF is similar to hereditary gingival fibromatosis, but without the associated family history. Fibromatosis may cover exposed tooth surfaces, causing esthetic and functional problems.

The most prominent pathologic manifestations of this disease are an excessive accumulation of extracellular matrix, predominantly type I collagen, and increased expression of matrix metalloproteinases [46], which may induce the degradation of collagen. Many studies have detected increased levels of type I collagen mRNA and protein in both tissue and cells derived from the gingiva of IGF patients. However, the molecular and functional characteristics of these cells remain unknown.

Although histone deacetylase inhibitors (HDACi) were initially studied for their ability to increase gene expression, they have emerged as potent anti-inflammatory agents [7] due to their ability to promote osteogenic differentiation of stem cells [8] Their pleiotropic effects impact nearly every aspect of cancer biology [9-13], inhibiting cell proliferation and up-regulating cell-cycle inhibitors (such as p21 Waf/Cip1) expressed in tumors [14]. As global HDACi, valproic acid, suberoylanilide hydroxamic acid, trichostatin A (TSA), and panobinostat (LBH589) [15,16] have positive effects on cancers. However, the effects of HDACi on the proliferation of IGF remain unclear.

In this study, we investigated the cellular characteristics of normal gingival cells and cells from IGF. In vitro results demonstrated that TSA and LBH589 inhibit the proliferation of IGF cells partly due to the induction of apoptosis and cell-cycle arrest in G1 phase.

\section{Materials and methods}

Cell culture: IGF and normal gingival tissues were obtained in accordance with guidelines set by the Tianjin Medical University School of Stomatology; all patients provided written informed consent. Normal gingival samples were collected from clinically healthy subjects with no systemic disease and no history of periodontal disease. IGF patients required surgery to shape their gums.

*Corresponding author: Dayong Liu, DDS, PhD, Department of Endodontics \& Laboratory for Dental Stem Cells and Endocrine Immunology, Tianjin Medical University School of Stomatology, Qi Xiang Tai Road No.12, Tianjin, 300070, PR China. Tel: 86-22-23332095; Fax: 86-22-23332100; E-mail: dyliuperio@tmu.edu.cn

Received January 13, 2016; Accepted February 05, 2016; Published February 12, 2016

Citation: Jia Z, Feng C, Wang Y, Li J, Zhang T, et al. (2016) Histone Deacetylase Inhibitors can Repress Proliferation and Induce Apoptosis in Gingiva Progenito Cells from Idiopathic Gingival Fibromatosis. J Stem Cell Res Ther 6: 327. doi:10.4172/2157-7633.1000327

Copyright: (c) $2016 \mathrm{Jia}$ Z, et al. This is an open-access article distributed unde the terms of the Creative Commons Attribution License, which permits unrestricted use, distribution, and reproduction in any medium, provided the original author and source are credited. 
Cells were gently separated from IGF and normal gingival tissues and digested in a solution of $3 \mathrm{mg} / \mathrm{mL}$ collagenase type I (SigmaAldrich, USA) and $4 \mathrm{mg} / \mathrm{mL}$ dispase (Sigma-Aldrich). The mixture was placed in a $37^{\circ} \mathrm{C}$ water bath for $40-60$ min and shaken once every $5 \mathrm{~min}$. Single-cell suspensions were obtained by passing the cells through a $70-\mu \mathrm{m}$ strainer. Cells were cultured in a humidified, $5 \% \mathrm{CO}_{2}$ incubator at $37^{\circ} \mathrm{C}$ in Dulbecco's Modified Eagle Medium (Hyclone, USA) supplemented with $20 \%$ fetal bovine serum (Gibco, USA), 2 $\mathrm{mM}$ glutamine, $100 \mu \mathrm{g} / \mathrm{mL}$ penicillin, and $100 \mu \mathrm{g} / \mathrm{mL}$ streptomycin (Gibco). Culture medium was changed every 2-3 days. When the fused cells had grown to $80 \%$ confluence, they were digested with $0.25 \%$ trypsin containing $0.02 \%$ ethylenediaminetetraacetic acid for $\sim 1 \mathrm{~min}$, then centrifuged at $300 \mathrm{~g}$ for $10 \mathrm{~min}$. The supernatant was discarded and cells were seeded in culture flasks and passaged at 1:3. Cell growth was observed daily under an inverted microscope, and cell morphology and growth were recorded and photographed. All experiments were performed using cells between the third and forth passages.

Alkaline phosphatase (ALP) activity and staining and alizarin red staining: To induce osteogenic differentiation, N-GMSCs and H-GMSCs $\left(2 \times 10^{3} / \mathrm{cm}^{2}\right)$ were seeded in 6-well plates, grown to $80 \%$ confluence, and incubated in differentiation medium containing 50 $\mathrm{mg} / \mathrm{mL}$ ascorbate phosphate, $10 \mathrm{mM} \beta$-glycerophosphate, $10 \%$ fetal bovine serum, and $10 \mathrm{nM}$ dexamethasone. Culture medium was changed every 2 days.

For ALP staining, cells were cultured for 7 days, washed twice with PBS, and fixed in medium containing $66 \%$ acetone, $25.5 \%$ citrate, and $8.5 \%$ formaldehyde. We discarded the medium and washed the cells twice with distilled water; $2 \mathrm{~mL}$ ALP staining liquid (ALP kit, SigmaAldrich) were added at room temperature for $15 \mathrm{~min}$, and the cells were viewed with a microscope. After 7 days of culture, the cells were washed twice with PBS, $300 \mu \mathrm{L}$ lysis buffer were added for $15 \mathrm{~min}$, and the supernatant was collected. Then, $100 \mu \mathrm{L}$ of solution $(50 \mu \mathrm{L}$ ALP buffer solution plus $50 \mu \mathrm{L}$ stock substrate Sol) were added to $10 \mu \mathrm{L}$ of the supernatant at $37^{\circ} \mathrm{C}$ for $15 \mathrm{~min}$, after which stop solution was added and absorbance was measured at $450 \mathrm{nM}$.

To detect mineralization, cells were induced for 2-3 weeks, fixed with $70 \%$ ethanol, and stained with $40 \mathrm{mM}$ alizarin red S (SigmaAldrich). Samples were then dissolved in distilled water for $5 \mathrm{~min}$, washed with distilled water, and observed via microscopy.

To quantitatively determine calcium levels, alizarin red S was removed with $10 \%$ cetylpyridinium chloride in $10 \mathrm{mM}$ sodium phosphate for $30 \mathrm{~min}$ at room temperature. The calcium concentration was determined by measuring the absorbance of the solution at $562 \mathrm{~nm}$ on a multiplate reader and compared it to a standard curve of calcium dilutions in the same solution. The final calcium level in each group was normalized to the total protein concentration measured in a duplicate plate.

Oil red O staining: To induce adipocyte differentiation, N-GMSCs and H-GMSCs $\left(2 \times 10^{3} / \mathrm{cm}^{2}\right)$ were seeded in 6-well plates, grown to $80 \%$ confluence, and incubated in adipocyte differentiation basal medium (Gibco) for 28 days. Cells were washed with PBS and fixed in 10\% (v/v) neutralized formalin ( $\mathrm{pH} \mathrm{7.2)}$ ) for $10 \mathrm{~min}$ at room temperature. After one wash with PBS, $60 \%(\mathrm{v} / \mathrm{v})$ isopropanol was added for $1 \mathrm{~min}$ before the cells were stained with $0.18 \%(\mathrm{w} / \mathrm{v})$ oil red O (Sigma-Aldrich) for $15 \mathrm{~min}$ at room temperature. Cells were washed with $60 \%(\mathrm{v} / \mathrm{v})$ isopropanol and PBS and observed under phase-contrast microscopy.

Cell proliferation and viability: Cell proliferation and viability were measured using the colorimetric 3-(4,5-dimethylthazol-2-yl)- 2,5-diphenyltetrazolium bromide (MTT) assay (Solarbio, Beijing). Briefly, N-GMSCs and H-GMSCs $\left(3 \times 10^{3}\right.$ cell/well) were seeded in 96well plates and cultured for $24 \mathrm{~h}$. Approximately $10 \mu \mathrm{L}$ of premixed optimized dye solution were added after 1, 2, 3, 4, 5, or 6 days. Cells were incubated in $5 \% \mathrm{CO}_{2}$ at $37^{\circ} \mathrm{C}$ for $4 \mathrm{~h} ; 100 \mu \mathrm{L}$ of a solubilization/ stop solution were added to solubilize the formazan product. Each condition was prepared in triplicate and reactions were assessed with an enzyme-linked immunosorbent assay reader at $490 \mathrm{~nm}$.

To determine the effects of TSA and LBH589 (Selleckchem, USA), H-GMSCs $\left(6 \times 10^{3}\right.$ cell/well) were seeded and cultured with $0,50,100$, 200, 500, or $1000 \mathrm{nM}$ TSA or LBH589 in 96-well plates for $48 \mathrm{~h}$. Cell proliferation was assessed with the cell counting kit- 8

Cell-cycle progression and apoptosis: Flow cytometry was used to determine the influence of TSA and LBH589 on cell-cycle progression and apoptosis. Cells were seeded $\left(1 \times 10^{6}\right.$ cells/well $)$ in 6-well plates for 24 $\mathrm{h}$ before the addition of Dulbecco's Modified Eagle Medium containing TSA ( $50 \mathrm{nM}, 500 \mathrm{nM}, 1000 \mathrm{nM})$ or LBH589 (50 nM, $500 \mathrm{nM}, 1000 \mathrm{nM})$ for $48 \mathrm{~h}$. Positive controls contained cell cultures without HDACi.

For the analysis of apoptosis, H-GMSCs were washed with PBS and harvested in annexin binding buffer (Invitrogen, USA). Cells $\left(1 \times 10^{6} / \mathrm{mL}, 100 \mu \mathrm{L}\right)$ were treated with $5 \mu \mathrm{L}$ annexin $\mathrm{V}$ (Invitrogen) and $1 \mu \mathrm{L}$ propidium iodide (from $100 \mu \mathrm{g} / \mathrm{mL}$ stock solution) at room temperature for $15 \mathrm{~min}$. Annexin binding buffer $(400 \mu \mathrm{L})$ was added, and cell sorting and analysis were performed on a FACSCalibur flow cytometer (BD Biosciences, USA).

For cell-cycle analysis, H-GMSCs were harvested and washed in PBS. Cells were fixed in cold $70 \%$ ethanol for $12 \mathrm{~h}$ at $4^{\circ} \mathrm{C}$ and washed three times in PBS. Cells were centrifuged at $850 \mathrm{x} g$ and the supernatant was discarded. Cells were re-suspended in $0.5 \mathrm{~mL}$ PBS and treated with RNase $(2.5 \mu \mathrm{L}$ of a $10 \mathrm{mg} / \mathrm{mL}$ stock), after which $25 \mu \mathrm{L}$ propidium iodide (from a $1 \mathrm{mg} / \mathrm{mL}$ stock solution) were added. Cells were placed in a $37^{\circ} \mathrm{C}$ water bath for $15 \mathrm{~min}$, then subjected to flow cytometry.

Reverse transcriptase polymerase chain reaction (RT-PCR): $\mathrm{H}$ GMSCs were seeded $\left(5 \times 10^{4}\right.$ cells/well) into a 6 -well culture dish and TSA or LBH589 was added after $48 \mathrm{~h}$. The applied concentrations of HDACi were determined based on results from our assays of proliferation, cell cycle, and apoptosis. Positive controls contained no HDACi. N-GMSCs were also seeded $\left(5 \times 10^{4}\right.$ cells/well) into a 6-well culture dish and cultured without HDACi. Total RNA was isolated from H-GMSCs and N-GMSCs with Trizol reagent (Invitrogen) and cDNA was prepared using the HiFi-MMLV RT-PCR kit (ComWin Biotech, Beijing) according to the manufacturer's instructions. RT-PCR was performed with the following primer sequences: glyceraldehyde 3-phosphate dehydrogenase: forward, 5'-GTCAGTGGTGGACCTGACCT-3', reverse, 5'-AGGGGAGATTCAGTGTGGTG-3'; p21: forward, 5'-GGTGGCAGTAGAGGCTATGG-3', reverse, 5'-ATTCAGCATTGTGGGAGGAG-3'. Amplification was performed for 30-35 cycles after an initial $30 \mathrm{~s}$ denaturation at $95^{\circ} \mathrm{C}$, annealing occurred for $30 \mathrm{~s}$ at 56$60^{\circ} \mathrm{C}$, and extension occurred for $30 \mathrm{~s}$ at $72^{\circ} \mathrm{C}$, with a last extension for $5 \mathrm{~min}$ at $72^{\circ} \mathrm{C}$. RT-PCR products were separated via agarose gel electrophoresis and stained with ethidium bromide.

\section{Statistical analysis}

All statistical calculations were performed using SPSS 19.0. Student's $t$ test or one-way analysis of variance was performed to determine statistical significance. p-values $<0.05$ were considered significant. 
Citation: Jia Z, Feng C, Wang Y, Li J, Zhang T, et al. (2016) Histone Deacetylase Inhibitors can Repress Proliferation and Induce Apoptosis in Gingiva Progenitor Cells from Idiopathic Gingival Fibromatosis. J Stem Cell Res Ther 6: 327. doi:10.4172/2157-7633.1000327

\section{Results}

\section{Human IGF tissues contain cells with the characteristics of GMSCs}

Cells were isolated from normal gingiva and IGF tissues using previously described standardized methods and were enzymatically expanded. During the first and second passages, H-GMSCs had the same shape as N-GMSCs (Figure 1).

After 1 week of mineralization-induced differentiation, N-GMSCs and H-GMSCs expressed ALP (Figure 2A) and displayed ALP activity (Figure 2B), with no significant differences between groups. After 3 weeks of differentiation, N-GMSCs and H-GMSCs began to show mineralized nodules that were stained by alizarin red $S$ (Figure 2C). However, N-GMSCs were associated with a greater number of calcified nodules and stronger staining than H-GMSCs (Figure 2C). De-staining revealed higher calcium concentration in N-GMSCs than that in H-GMSCs (Figure 2D). After 4 weeks of culture in adipogenic induction medium, N-GMSCs and H-GMSCs produced lipid droplets, the hallmark of functional adipogenesis (Figure 2E). Taken together, these results indicate that despite differences between normal gingiva and IGF, IGF harbors cells with features of mesenchymal stem cells.

\section{H-GMSCs have greater proliferation abilities than N-GMSCs}

Gingival enlargement, the overgrowth of gingiva, is characterized by expansion and accumulation of the connective tissue, with increased numbers of cells. We applied the MTT assay to detect cell numbers after $1,2,3,4,5$, and 6 days of culture. Proliferation was significantly higher in $\mathrm{H}-\mathrm{GMSC}$ than N-GMSCs $(0.155 \pm 0.003,0.164 \pm 0.003$,
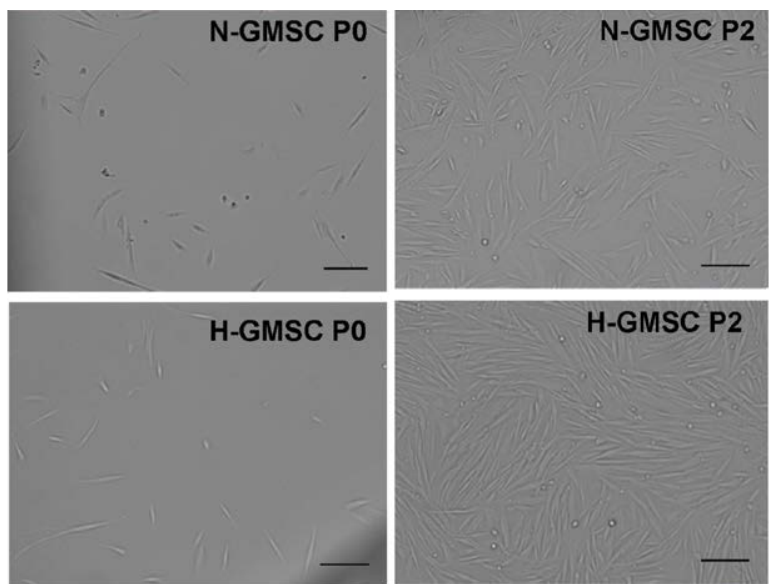

Original (P0) and second-generation (P2) H-GMSCs had the same shape as N-GMSCs (scale bar=200 $\mu \mathrm{m}$ ).

Figure 1: Isolation of cells from normal gingiva and IGF.

$0.218 \pm 0.005,0.246 \pm 0.004,0.317 \pm 0.007,0.369 \pm 0.006$ in N-GMSCs; $0.150 \pm 0.004,0.254 \pm 0.004,0.380 \pm 0.005,0.439 \pm 0.004,0.539 \pm 0.006$, $0.586 \pm 0.006$ in $\mathrm{H}-\mathrm{GMSCs}$, respectively; $\mathrm{n}=5, \mathrm{P}<0.05$; Student's t test, Figure 3).

\section{TSA and LBH589 inhibit H-GMSC proliferation}

Here, we carried out the first investigations of the effects of the HDACi drugs TSA and LBH589 on the proliferation of H-GMSCs.

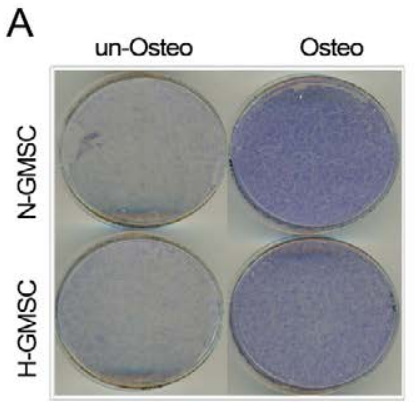

B

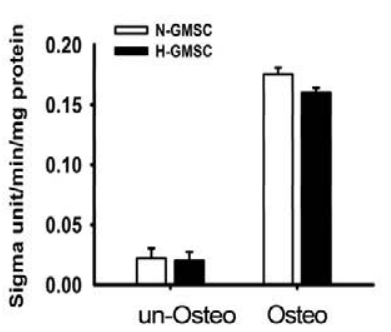

C

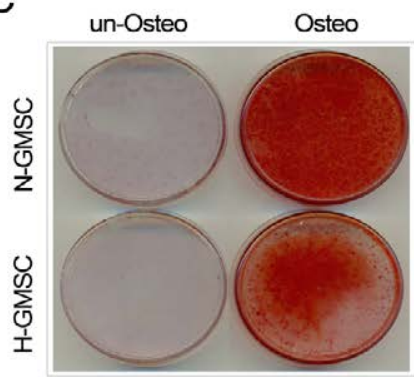

D

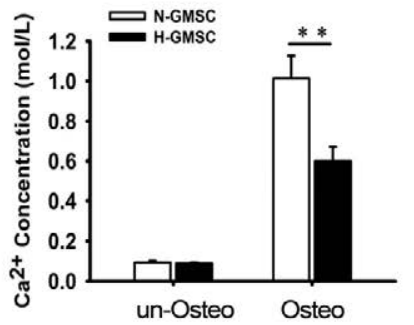

$E$

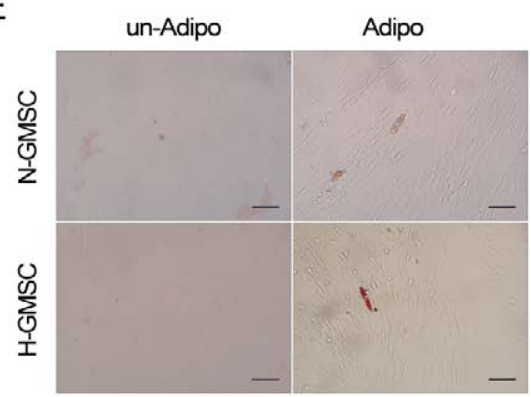

(A) ALP staining of N-GMSCs and H-GMSCs.

(B) ALP activity in N-GMSCs and H-GMSCs did not differ ( $n=5, P<0.1$; Student's t test).

(C) Alizarin red S staining of N-GMSCs and H-GMSCs under osteogenic induction.

(D) Calcium concentrations in N-GMSCs were higher than in H-GMSCs ( $n=5, P<0.01$; Student's t test).

(E) Oil red O staining of N-GMSCs and H-GMSCs under adipogenic induction (scale bar=200 $\mu \mathrm{m}$ ).

Figure 2: Cells from IGF (H-GMSCs) express some characteristics of mesenchymal stem cells. 


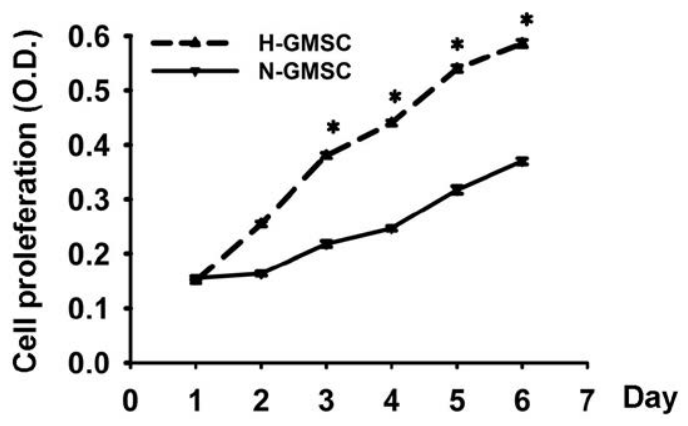

Results from the MTT assay are shown $(n=5, P<0.05$; Student's $t$ test).

Figure 3: H-GMSCs undergo significantly more proliferation than N-GMSCs.

After $48 \mathrm{~h}$ of culture, CCK8 assays showed that TSA and LBH589 suppressed H-GMSC proliferation in a dose-dependent manner, with the largest decrease in absorbance at doses of $1000 \mathrm{nM}$ (O.D. value, 0.30 $\pm 0.038,0.30 \pm 0.054,0.31 \pm 0.034,0.31 \pm 0.023,0.27 \pm 0.024,0.21 \pm$ 0.021 by TSA and $0.27 \pm 0.039,0.30 \pm 0.050,0.30 \pm 0.029,0.27 \pm 0.010$, $0.22 \pm 0.029,0.21 \pm 0.010$ by LBH589, respectively, $\mathrm{p}<0.05$ Figure 4$)$.

We next investigated apoptosis in H-GMSCs after exposure to various doses of TSA or LBH589 for $48 \mathrm{~h}$. As an early marker of apoptosis, annexin $\mathrm{V}$ was added to the culture medium and cells were analyzed via flow cytometry. Significantly more apoptotic cells were found in populations of H-GMSCs treated with $1000 \mathrm{nM}$ TSA or LBH589 than in populations exposed to lower drug concentrations $(3.38 \pm 0.32 \%$ in control; $4.71 \pm 0.18 \%, 8.33 \pm 0.32 \%, 11.02 \pm 0.20 \%$ stimulated by different concentrations of the TSA; $6.04 \pm 0.17 \%, 8.91$ $\pm 0.16 \%, 11.20 \pm 0.23 \%$ stimulated by different concentrations of the LBH589, respectively; $\mathrm{n}=5, \mathrm{P}<0.05$, one-way analysis of variance, Figure 5). Next, we used propidium iodide staining to evaluate cellcycle progression after the addition of $0,50,100,200,500$, or $1000 \mathrm{nM}$ TSA or LBH589. The highest doses of both drugs arrested cell-cycle progression after $48 \mathrm{~h}$ at the G1/S phase. The proliferation index was $16.56 \pm 0.70 \%$ in the $1000 \mathrm{nM}$ TSA group and $17.30 \pm 1.03 \%$ in the
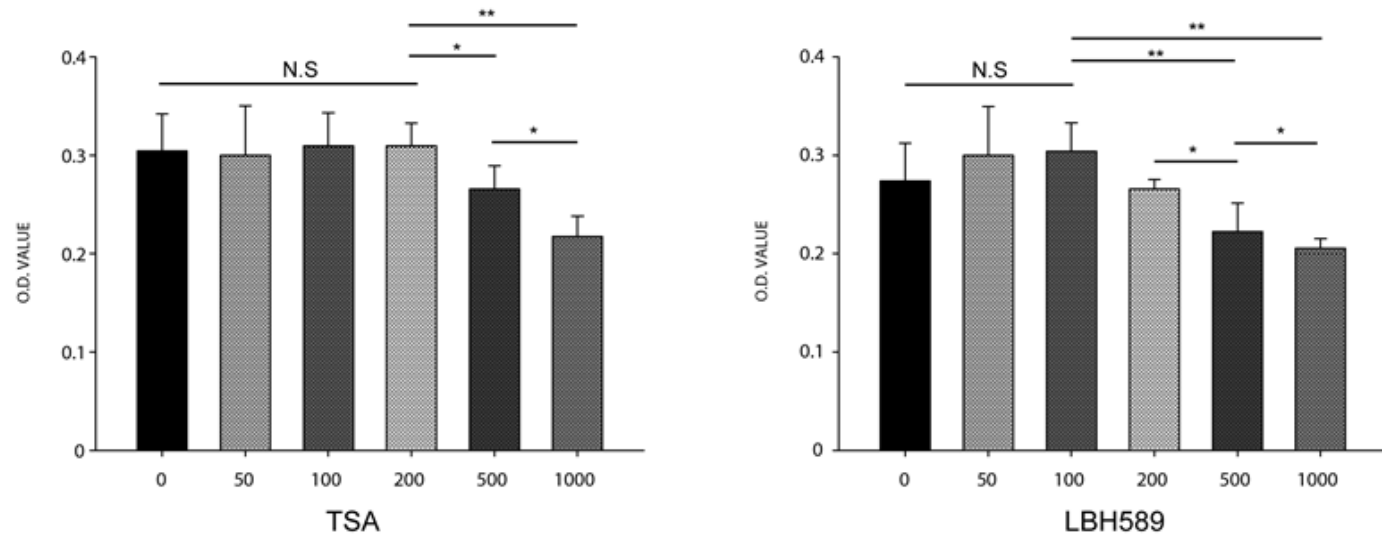

H-GMSCs were exposed to $0,50,100,200,500$, or $1000 \mathrm{nM}$ TSA or LBH589. After $48 \mathrm{~h}$ of culture, CCK8 assay showed that TSA or LBH589 inhibited the proliferation of $\mathrm{H}-\mathrm{GMSC}$ in a dose-dependent manner

Figure 4: TSA and LBH589 inhibit the proliferation of IGF cells.
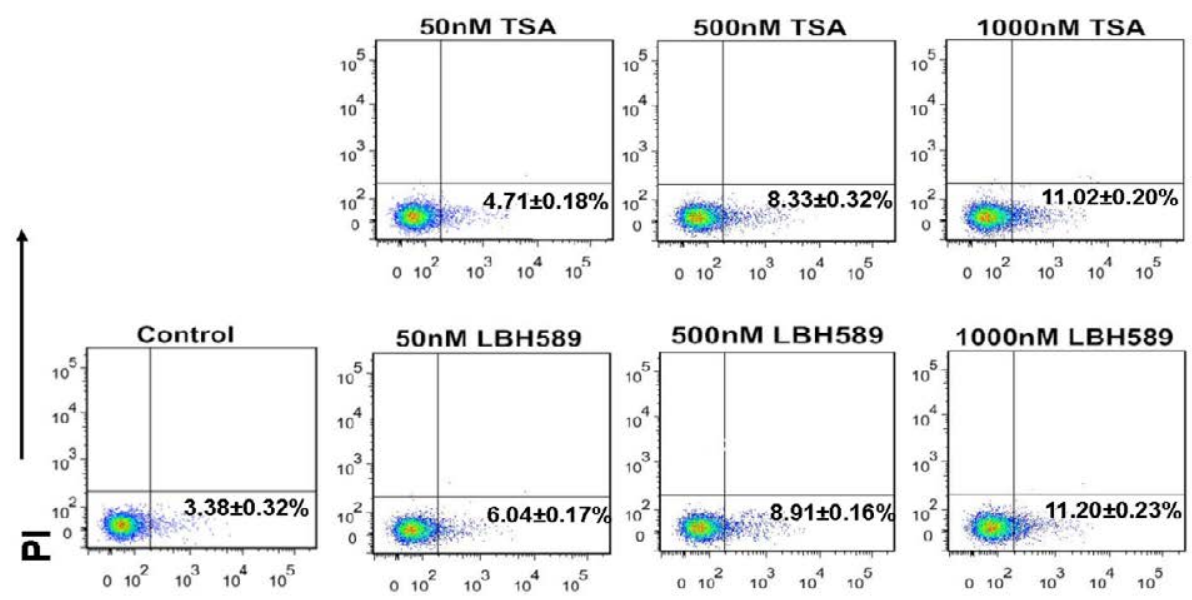

Annexin V

The apoptosis in H-GMSCs at 0,50,100, 200, 500 and $1000 \mathrm{nM}$ TSA or LBH589. The apoptosis rates in H-GMSCs were treated by different concentration of TSA or LBH589. The dose of $1000 \mathrm{nM}$ most effectively induced propidium iodide-positive, annexin-positive apoptosis ( $\mathrm{n}=5$, $P<0.05$, one-way analysis of variance).

Figure 5: Exposure to TSA or LBH589 induces H-GMSCs apoptosis in a dose-dependent manner. 

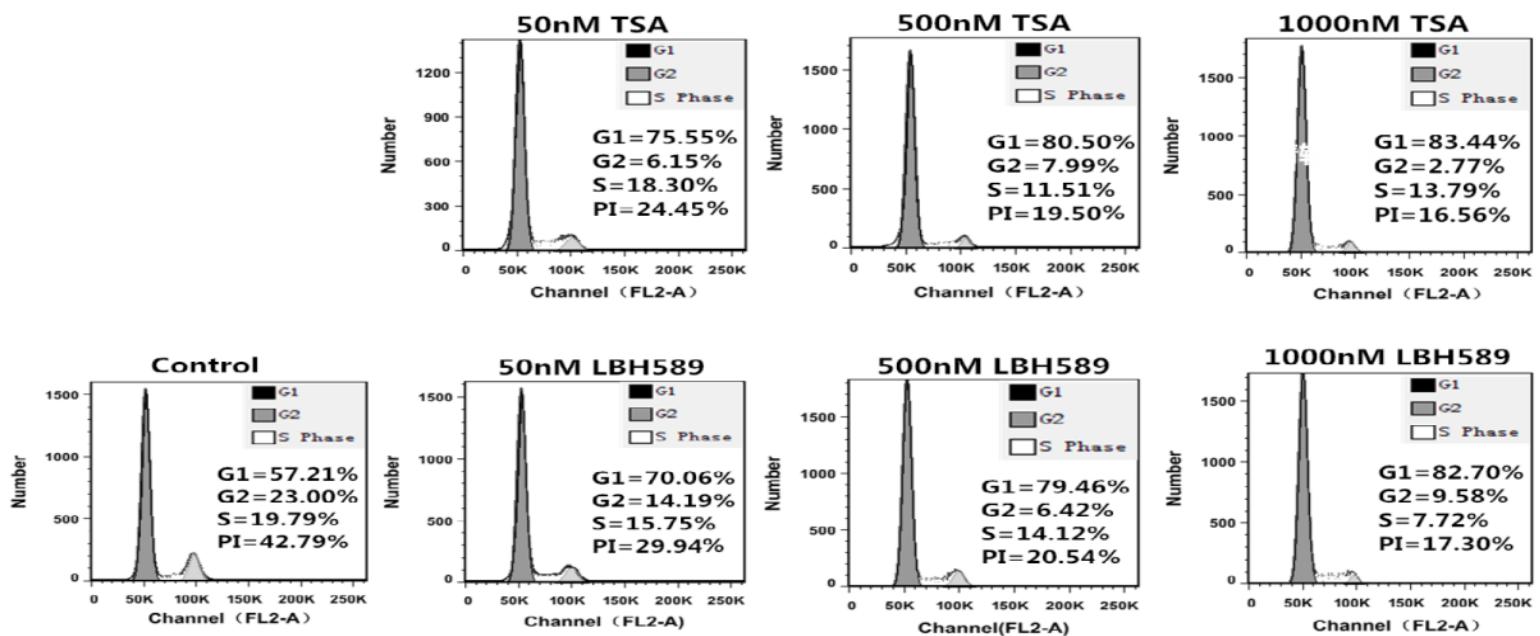

Exposure to TSA or LBH589 arrested cell-cycle progression at G1/S, as revealed by flow cytometry. Propidium iodide staining and flow cytometry confirmed that the percentage of $\mathrm{H}-\mathrm{GMSC}$ in $\mathrm{G} 1$ increased after adding TSA. H-GMSCs in G1 increased after addingLBH589. Propidium iodide-stained cells=S cells+G2 cells/G1 cells $+S$ cells $+G 2$ cells; $n=5, P<0.01$; one-way analysis of variance).

Figure 6: TSA and LBH589 influence cell-cycle progression in H-GMSCs.

$1000 \mathrm{nM}$ LBH589 group, values that were lower than those associated with the other drug doses $(42.49 \pm 1.69 \%$ in control, $28.89 \pm 1.04 \%$, $20.76 \pm 0.84 \%, 16.56 \pm 0.70 \%$ stimulated by different concentrations of the TSA; $24.24 \pm 1.38 \%, 20.46 \pm 0.84 \%, 17.30 \pm 1.03 \%$ stimulated by different concentrations of the LBH589, respectively; $\mathrm{n}=3, \mathrm{P}<0.01$, one-way analysis of variance, Figure 6). Thus, these HDACi repressed $\mathrm{H}$-GMSC proliferation in a dose-dependent manner.

\section{TSA and LBH589 up-regulate the expression of $\mathrm{p}^{21^{\text {Waf/Cip1 }}}$ in H-GMSCs}

Next, we investigated the mechanism by which TSA and LBH589 inhibit H-GMSC proliferation. We measured $\mathrm{p} 21^{\text {Waf/Cip1 }} \mathrm{mRNA}$ levels in N-GMSCs and H-GMSCs via RT-PCR; these levels were lower in $\mathrm{H}$-GMSCs than in N-GMSCs (Figure 7A,B). Addition of $1000 \mathrm{nM}$ TSA or LBH589 to the culture medium for $48 \mathrm{~h}$ resulted in levels of $\mathrm{p} 21^{\text {Waf }}$ ${ }^{C i p 1}$ mRNA that were higher than levels in control cultures without drug (Figure 7C, D), supporting our observation that progression into G1 was retarded in HDACi-exposed cells.

\section{Discussion}

Epigenetic mechanisms, such as reversible factors (histone modifications, DNA methylation, non-coding RNA) involved in transcriptional and post-transcriptional regulation of proteins, are indispensable for the control of cancerous phenotypes [17] However, DNA methylation, histone deacetylation, and methylation [18] may participate in the regulation of transcription and are important regulatory factors in cell proliferation. Histone acetylation $[19,20]$, a reversible dynamic process, is regulated by histone acetyltransferases and histone deacetylases [21,22], both of which play vital roles in the regulation of transcription. Histone acetyltransferases are recruited to promoter regions by transcription factors in order to unfold the local chromatin structure, which enables the formation of transcriptioninitiation complexes and other protein complexes to control gene expression. High expression of histone deacetylases is closely correlated with tumorigenesis; thus, inhibiting the expression of these enzymes may constitute a therapeutic strategy for patients with tumors.

IGF is a rare lesion characterized by proliferative benign overgrowth of gingival tissues. The results reported here comprise the first demonstration that HDACi inhibit proliferation in IGF. Previous studies have shown that HDACi such as TSA, sodium butyrate, and valproic acid can inhibit cancer-cell growth in vitro and in vivo, inducing apoptosis. Other studies reported that valproic acid inhibits the proliferation of BGC-823 gastric carcinoma cells by arresting cells in G1 and inducing apoptosis [23].

Mesenchymal stem cells from normal human and hyperplastic gingival tissues were previously isolated and characterized [24]. In the present investigation, we confirmed that H-GMSCs from IGF share features with N-GMSCs, which can undergo multi-directional differentiation. The proliferation of $\mathrm{H}$-GMSCs was significantly higher than that of N-GMSCs. After exposing H-GMSCs to TSA or LBH589 for $48 \mathrm{~h}$, we observed that apoptosis increased in a dosedependent manner; a dose of $1000 \mathrm{nM}$ was most effective. Additionally, progression into G1 phase significantly differed between HDACitreated cells and unexposed cells. These results confirm that TSA and LBH589 play obvious roles in inhibiting the proliferation of H-GMSCs in vitro.

One of the major regulators of cell-cycle progression is the cyclin-dependent kinase inhibitor $\mathrm{p} 21^{\text {Waf/Cip1 } 1}[25,26]$, a member of the CIP/KIP family. p $21^{\text {Waf/Cipl }}$ is a downstream mediator of p53 activity [27]; it mediates growth arrest by inhibiting the action of G1 cyclindependent kinases, yielding cell-cycle arrest and/or apoptosis [28]. Previous research on HDACi focused on the up-regulation of $\mathrm{p} 21^{\text {Waf/ }}$ Cip1 [29]. Shen et al. [30] found that HDAC4 could repress the mRNA/ protein of $\mathrm{p} 21$ and in turn promoted the proliferation and migration of epithelial ovarian cancer cells. In epidermoid carcinoma, TSA induced cell growth inhibition through interfering with TSA -induced p21 activation [31]. So activation of p21 Waf/Cipl involves the acetylation of promoter chromatin, but the mechanism underlying remains poorly understood. Here, we observed that $\mathrm{p} 21^{\text {Waf/Cip1 }}$ mRNA levels were lower in H-GMSCs than in N-GMSCs. After exposure to $1000 \mathrm{nM}$ TSA or LBH589, these levels remarkably increased. Thus, the HDACi TSA and LBH589 may up-regulate the expression of $\mathrm{p} 21^{\text {Waf/Cipl }}$ to induce apoptosis and to block H-GMSC progression into G1, which decreases H-GMSC proliferation. 
Citation: Jia Z, Feng C, Wang Y, Li J, Zhang T, et al. (2016) Histone Deacetylase Inhibitors can Repress Proliferation and Induce Apoptosis in Gingiva Progenitor Cells from Idiopathic Gingival Fibromatosis. J Stem Cell Res Ther 6: 327. doi:10.4172/2157-7633.1000327

A

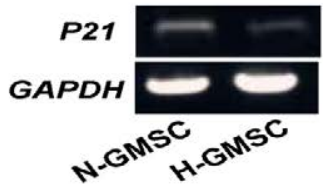

C

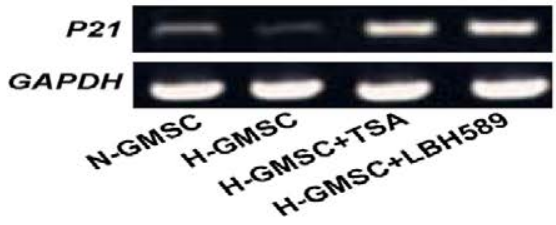

B

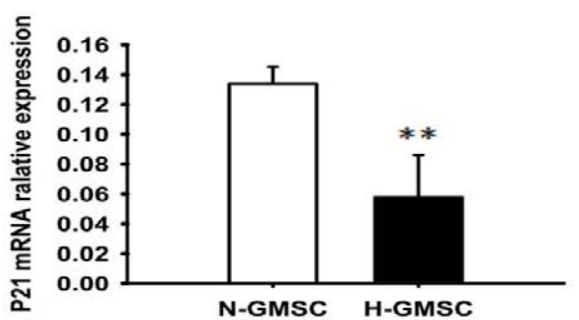

D

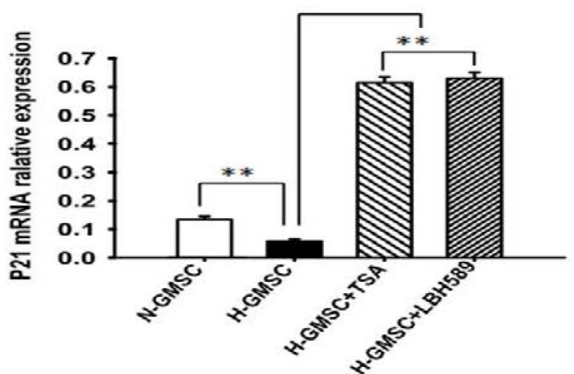

(A) RT-PCR of p21 $1_{\text {Waf/Cip1 }}$ mRNA in N-GMSCs and H-GMSCs.

(B) Expression of the gene encoding p21 ${ }^{\text {Wat/Cip1 }}$ was lower in H-GMSCs than in N-GMSCs $(n=5, P<0.01$; Student's t test).

(C) Addition of TSA or LBH589 stimulated H-GMSCs for $48 \mathrm{~h}$.

(D) p21 Waf/Cip1 $m R N A$ levels were up-regulated in H-GMSCs after exposure to TSA or LBH589 ( $n=5, P<0.01$; one-way analysis of variance).

Figure 7: Exposure to TSA or LBH589 increases the mRNA levels of $p 21^{\text {Waflipi } 1}$ in IGF cells.

In summary, IGF cells and cells from normal gingiva have similar characteristics. However, the osteogenic capability of H-GMSCs is weaker than that of N-GMSCs, and H-GMSCs undergo more growth. TSA and LBH589 exhibit anti-proliferative activity and potently induce apoptosis in IGF cells, affecting progression into $\mathrm{G} 1$ as well as $\mathrm{p} 21^{\text {Waf/Cip } 1}$ mRNA levels. We will further explore how the mechanism of HDACi affects proliferation and apoptosis in H-GMSCs. The present findings raise the possibility that HDACi may be particularly effective for the treatment of IGF.

\section{Funding}

This study was supported by research grant from National Nature Science Foundation of China (Grant No.81371109 to D.Y.L) and grant from Tianjin Research Program of Application Foundation and Advanced Technology (Grant No. 15JCYBJC50200 to Z.J.) and grant from Beijing Key Laboratory of Tooth Regeneration and Function Reconstruction Open Project (Grant No.2014QYZS02 to D.Y.L).

\section{References}

1. Coletta RD, Graner E (2006) Hereditary gingival fibromatosis: a systematic review. J Periodontol 77: 753-764. [PubMed]

2. Mohan RP, Verma S, Agarwal N, Singh U (2013) Non-syndromic hereditary gingival fibromatosis. BMJ Case Rep 12. [PubMed]

3. Chaturvedi $R$ (2009) Idiopathic gingival fibromatosis associated with generalized aggressive periodontitis: a case report. J Can Dent Assoc 75: 291 295. [PubMed]

4. Tipton DA, Howell KJ, Dabbous MK (1997) Increased proliferation, collagen, and fibronectin production by hereditary gingival fibromatosis fibroblasts. $J$ Periodontol 68: 524-530. [PubMed]

5. Goncalves Lda R, Oliveira GA, Borojevic R, Otazu IB, Feres-Filho EJ (2009) Expression of metalloproteinases and their tissue inhibitors in gingiva affected by hereditary gingival fibromatosis: analysis of three cases within a family. $J$ Periodontal Res 44: 714-717. [PubMed]

6. Martelli-Junior H, Cotrim P, Graner E, Sauk JJ, Coletta RD (2003) Effect of transforming growth factor-beta1, interleukin-6, and interferon-gamma on the expression of type I collagen, heat shock protein 47 , matrix metalloproteinase
(MMP)-1 and MMP-2 by fibroblasts from normal gingiva and hereditary gingival fibromatosis. J Periodontol 74: 296-306. [PubMed]

7. Grabiec AM, Korchynskyi O, Tak PP, Reedquist KA (2012) Histone deacetylase inhibitors suppress rheumatoid arthritis fibroblast-like synoviocyte and macrophage IL-6 production by accelerating mRNA decay. Ann Rheum Dis 71: 424-431. [PubMed]

8. Wang Y, Chen T, Yan H, Qi H, Deng C, et al. (2013) Role of histone deacetylase inhibitors in the aging of human umbilical cord mesenchymal stem cells. J Cell Biochem 114: 2231-2239. [PubMed]

9. Aghdassi A, Sendler M, Guenther A, Mayerle J, Behn CO, et al. (2012) Recruitment of histone deacetylases HDAC1 and HDAC2 by the transcriptional repressor ZEB1 downregulates E-cadherin expression in pancreatic cancer. Gut 61: 439-448. [PubMed]

10. Coffey DC, Kutko MC, Glick RD, Swendeman SL, Butler L, et al. (2000) Histone deacetylase inhibitors and retinoic acids inhibit growth of human neuroblastoma in vitro. Med Pediatr Oncol 35: 577-581. [PubMed]

11. Lindemann RK, Gabrielli B, Johnstone RW (2004) Histone-deacetylase inhibitors for the treatment of cancer. Cell cycle 3: 779-788. [PubMed]

12. Subramanian C, Jarzembowski JA, Halsey SM, Kuick R, Opipari AW, Jr, et al (2011) CLU blocks HDACl-mediated killing of neuroblastoma. Tumour Biol 32: 285-94. [PubMed]

13. Takai N, Ueda T, Nishida M, Nasu K, Narahara H (2006) A novel histone deacetylase inhibitor, Scriptaid, induces growth inhibition, cell cycle arrest and apoptosis in human endometrial cancer and ovarian cancer cells. Int J Mol Med 17: 323-329. [PubMed]

14. Lobjois V, Frongia C, Jozan S, Truchet I, Valette A (2009) Cell cycle and apoptotic effects of SAHA are regulated by the cellular microenvironment in HCT116 multicellular tumour spheroids. Eur J Cancer 45: 2402-2411. [PubMed]

15. Shi W, Lawrence YR, Werner-Wasik M, Andrews DW, Evans JJ, et al. (2016) Phase I study of panobinostat and fractionated stereotactic re-irradiation therapy (FSRT) for recurrent high grade gliomas. J Neurooncol. [PubMed]

16. Sun B, Fiskus W, Shah B, Qi J, Devaraj SGT, et.al. (2014) Superior PreClinical Activity of BET (Bromodomain and Extra terminal) Protein Antagonist Combined with Ibrutinib, Panobinostat or Carfilzomib Against Human Mantle Cell Lymphoma (MCL) Cells. Blood 126: 1565-1574. 
Citation: Jia Z, Feng C, Wang Y, Li J, Zhang T, et al. (2016) Histone Deacetylase Inhibitors can Repress Proliferation and Induce Apoptosis in Gingiva Progenitor Cells from Idiopathic Gingival Fibromatosis. J Stem Cell Res Ther 6: 327. doi:10.4172/2157-7633.1000327

17. Filion GJ, Defossez PA (2006) [Epigenetics and cancer]. Bull Cancer 93: 343347. [PubMed]

18. Gao R, Dong R, Du J, Ma P, Wang S, et al. (2013) Depletion of histone demethylase KDM2A inhibited cell proliferation of stem cells from apical papilla by de-repression of p15INK4B and p27Kip1. Mol Cell Biochem 379: 115-122. [PubMed]

19. Mahgoub M, Monteggia LM (2014) A role for histone deacetylases in the cellular and behavioral mechanisms underlying learning and memory. Learn Mem 21: 564-568. [PubMed]

20. Thiagalingam S, Cheng KH, Lee HJ, Mineva N, Thiagalingam A, et al. (2003) Histone deacetylases: unique players in shaping the epigenetic histone code. Ann N Y Acad Sci 983: 84-100. [PubMed]

21. Dekker FJ, Haisma HJ (2009) Histone acetyl transferases as emerging drug targets. Drug Discov Today 14: 942-948. [PubMed]

22. Kouzarides T (2007) Chromatin modifications and their function. Cell 128: 693705. [PubMed]

23. Zhao X, Yang W, Shi C, Ma W, Liu J, et al. (2011) The G1 phase arrest and apoptosis by intrinsic pathway induced by valproic acid inhibit proliferation of BGC-823 gastric carcinoma cells. Tumour boil 32: 335-346. [PubMed]

24. Tang L, Li N, Xie H, Jin Y (2011) Characterization of mesenchymal stem cells from human normal and hyperplastic gingiva. J cell physiol 226: 832-842. [PubMed]
25. Dehennaut V, Loison I, Boulay G, Van Rechem C, Leprince D (2013) Identification of p21 (CIP1/WAF1) as a direct target gene of HIC1 (Hypermethylated In Cancer 1). Biochem Biophys Res Commun 43: 49-53. [PubMed]

26. Foertsch F, Teichmann N, Kob R, Hentschel J, Laubscher U, et al. (2013) S100A11 is involved in the regulation of the stability of cell cycle regulator p21(CIP1/WAF1) in human keratinocyte HaCaT cells. FEBS J 280: 3840-3853. [PubMed]

27. Sachweh MC, Drummond CJ, Higgins M, Campbell J, Lain S (2013) Incompatible effects of p53 and HDAC inhibition on p21 expression and cell cycle progression. Cell Death Dis 4: e533. [PubMed]

28. Zhong D, Gu C, Shi L, Xun T, Li X, Liu S, et al. (2014) Obatoclax induces G1/G0-phase arrest via p38/p21(waf1/Cip1) signaling pathway in human esophageal cancer cells. J Cell Biochem 115: 1624-1635. [PubMed]

29. Jafary H, Ahmadian S, Soleimani M (2014) The enhanced apoptosis and antiproliferative response to combined treatment with valproate and nicotinamide in MCF-7 breast cancer cells. Tumour Biol 35: 2701-2710. [PubMed]

30. Shen YF, Wei AM, Kou Q, Zhu QY, Zhang L (2016) Histone deacetylase 4 increases progressive epithelial ovarian cancer cells via repression of p21 on fibrillar collagen matrices. Oncol Rep 35: 948-954. [PubMed]

31. Hao ZF, Su YM, Wang CM, Yang RY (2015) Activating transcription factor 3 interferes with p21 activation in histone deacetylase inhibitor-induced growth inhibition of epidermoid carcinoma cells. Tumour Biol 36: 1471-1476. [PubMed] 